Journal An-Nafs: Kajian Penelitian Psikologi

https://ejournal.iai-tribakti.ac.id/index.php/psikologi

e-ISSN: 2549-6166

p-ISSN: 2528-0600

DOI: $10.33367 /$ psi.v5i1.951

Submitted: 2019-10-13

Revised : 2020-01-09

Accepted : 2020-01-21

Published: 2020-06-01

\title{
KEPRIBADIAN BIG FIVE TERHADAP IMPULSIVE BUYING BEHAVIOR PADA MAHASISWI FAKULTAS EKONOMI DAN BISNIS
}

\author{
Putri Puji Astutik1, Tutut Chusniyah ${ }^{2}$, Diantini Ida Viatrie \\ 1putripujia23@gmail.com, 2tutut.chusniyah.fppsi@um.ac.id, ${ }^{3}$ diantini.ida.fppsi@um.ac.id \\ Universitas Negeri Malang
}

\begin{abstract}
College students are individuals who enter the transition from adolescence to adulthood. In this period, they have more opportunities to explore various values and lifestyles. Individuals are looking for experiences that will eventually form personalities. Personality can influence individuals who make risky decisions. Decision-making immediately without prior consideration can make them behave impulsively without thinking about the effect. This study aims to determine the effect of big five personalities on impulsive buying behavior on students of the Faculty of Economics and Business, Airlangga University, Surabaya. This study uses a quantitative approach, the collected data were analyzed using multiple linear regression. Based on the analysis results obtained three conclusions, 1) Most of the students of economics and business at Airlangga University Surabaya have big five personalities that tend to be dominant; 2) Most of the economics and business students of Airlangga University Surabaya have low impulsive buying behavior; 3) Big five personality influences impulsive buying behavior in economics and business students of Airlangga University Surabaya, conscientiousness has a greater influence than extraversion, agreeableness, neuroticism, and openness to experience.
\end{abstract}

Keywords: Personality, Big five, Impulsive buying behavior

\begin{abstract}
Abstrak
Mahasiswa merupakan individu yang memasuki masa transisi dari remaja menuju dewasa. Pada periode ini mereka lebih banyak peluang untuk mengeksplorasi berbagai nilai dan gaya hidup. Individu mencari pengalaman-pengalaman yang akhirnya akan membentuk kepribadian. Kepribadian dapat mempengaruhi individu yang memungkinkan mengambil keputusan beresiko. Pengambilan keputusan segera tanpa adanya pemikiran terlebih dahulu dapat membuat mereka berperilaku impulsif tanpa memikirkan dampaknya. Penelitian ini bertujuan untuk mengetahui pengaruh kepribadian big five terhadap impulsive buying behavior pada mahasiswi Fakultas Ekonomi dan Bisnis Universitas Airlangga Surabaya. Penelitian ini menggunakan pendekatan kuantitatif, data yang terkumpul dianalisis menggunakan regresi linier berganda. Berdasarkan hasil analisis diperoleh tiga kesimpulan, yaitu 1) Sebagian besar mahasiswi ekonomi dan bisnis Universitas Airlangga Surabaya memiliki kepribadian big five cenderung dominan; 2) sebagian besar mahasiswi ekonomi dan bisnis Universitas Airlangga Surabaya memiliki impulsive buying behavior rendah; 3) kepribadian big five berpengaruh terhadap impulsive buying behavior pada mahasiswi ekonomi dan bisnis Universitas Airlangga Surabaya, kepribadian conscientiousness merupakan kepribadian yang memiliki pengaruh lebih besar dibandingkan dengan extraversion, agreeableness, neuroticism, dan openness to experience.
\end{abstract}

Kata Kunci: Kepribadian, Big five, Impulsive buying behavior 


\section{PENDAHULUAN}

Mahasiswa adalah individu yang telah memasuki masa transisi antara remaja menuju dewasa (emerging adulthold), terjadi dari usia 18 sampai 25 tahun (Santrock, 2012). Mahasiswa cenderung merasa telah beranjak dewasa, mampu meluangkan lebih banyak waktunya dengan teman sebayanya, mempunyai lebih banyak peluang untuk mengeksplorasi berbagai nilai dan gaya hidup yang lebih beragam, dan lebih terbebas dari pengawasan orang tua. Sebagian besar waktu luang mereka yang dihabiskan dengan temantemannya dan kurangnya pengawasan dari orang tua membuat sebagian besar mereka terpengaruh oleh teman-temannya. Mereka berusaha untuk diterima oleh kelompok sosialnya. Salah satu cara yang bisa dilakukan yaitu dengan mengikuti kemanapun dan apapun yang dilakukan oleh kelompok sosialnya agar diterima dalam kelompoknya. Steinberg (dalam Santrock, 2012) mengatakan bahwa kehadiran teman sebaya dalam situasi beresiko meningkatkan kecenderungan remaja dalam mengambil keputusan beresiko.

Mahasiswa masa kini mengalami stres lebih besar dan merasa lebih depresi, merasa kewalahan dengan hal-hal yang harus mereka lakukan, dan mengalami kelelahan mental (Santrock, 2012). Mahasiswa yang mampu mengelola stres akan dapat mengontrol dirinya dan membuat keputusan-keputusan yang bijak. Mahasiswa yang menganggap dirinya sudah dewasa cenderung mempunyai pemikiran yang bijaksana dan realistik sehingga mampu membuat keputusan lebih baik. Di sisi lain, mahasiswa yang tidak mampu mengelola stresnya dengan baik akan mempengaruhi keputusan yang diambilnya. Sebagian besar orang mengambil keputusan dengan lebih baik pada saat mereka berada dalam keadaan tenang dibandingkan ketika sedang berada dalam keadaan emosi. Mahasiswa yang berada pada masa transisi masih terbawa sifat remaja yang mana pada remaja cenderung memiliki emosi yang kuat (Santrock, 2012).

Berbelanja merupakan aktivitas yang dapat membantu manusia untuk memenuhi kebutuhan hidupnya. Belanja dan membeli merupakan kegiatan yang menjadi rutinitas dalam kehidupan sehari-hari. Perilaku membeli mempunyai berbagai macam jenis, dari yang sangat terencana sampai yang tidak terencana. Berbagai strategi pemasaran agresif membuat masyarakat semakin terjebak dalam perkembangan gaya hidup konsumtif yang bersifat impulsif atau emosional dan bukan lagi rasional. Impulse buying adalah sebuah proses yang terjadi ketika konsumen mengalami dorongan secara tiba-tiba untuk membeli barang yang dia tidak bisa menolak.Ketidakmampuan konsumen untuk mengedalikan hasrat membeli barang apapun akan memaksa mereka melakukan apapun selama kebutuhannya terpenuhi (Lejoyeux \& Weinstein, 2010). 
Impulse buying adalah suatu tindakan pembelian yang dibuat tanpa rencana sebelumnya, atau keputusan pembelian dilakukan pada saat berada di dalam toko (Utami, 2010). Pembelian tanpa rencana seringkali disertai dorongan yang kuat dan perasaan gembira. Pembelian impulsif mempunyai perasaan yang kuat dan positif sehingga evaluasi terhadap suatu produk pada umumnya positif, dan bila kontrol dirinya rendah, maka konsumen akan membeli produk tersebut, meskipun sebelumnya tidak direncanakan.

Impulsive buying akan berdampak pada konsumen, baik jangka pendek maupun jangka panjang. Jangka pendek, konsumen akan mendapatkan nilai positif seperti menghilangkan stres, menimbulkan perasaan senang dan tenang setelah belanja, meningkatkan kepercayaan diri, serta meningkatkan hubungan interpersonal (Sari, 2016). Sedangkan dampak jangka panjang akan membuat pengeluaran tidak dapat dikendalikan akibat dari belanja yang tidak terkontrol (Workman, 2010) sehingga membuat konsumen pembeli impulsif meminjam uang hingga tidak akan segan mengambil barang atau uang yang bukan miliknya (Sari, 2016).

Impulse buying lebih bersifat emosional daripada rasional, olehnya konsumen lebih besar kemungkinannya untuk merasa tidak terkendali ketika membeli secara impulsif saat sedang berbelanja (Mahindra, 2018). Perempuan lebih banyak dipengaruhi oleh sisi emosionalnya dalam pengambilan keputusan sehingga menjadikan sebagian besarperempuan menjadi pelaku pembeli impulsif. Khan dkk., (2015) mengatakan bahwa konsumen dengan gender perempuan mempunyai perilaku belanja impulsif lebih tinggi dibandingkan konsumen gender laki-laki. Mahindra (2018) juga menunjukkan hasil penelitian yang sama dengan Khan, dkk., (2015) bahwa konsumen dengan gender perempuan mempunyai perilaku belanja impulsif lebih tinggi dibandingkan konsumen gender laki-laki. Hal ini terjadi karena perempuan lebih banyak dipengaruhi oleh sisi emosionalnya dalam mengambil keputusannya.

Beberapa faktor menentukan perilaku konsumen, antara lain variabel demografi, lingkungan sosial, dan perbedaan individu. Kepribadian telah lama menjadi alat penelitian yang penting guna mengetahui perilaku manusia dan big five merupakan salah satu teori yang saat ini banyak digunakan mengukur kepribadian seseorang. Chen dan Lee (2015) mengatakan bahwa big five berpengaruh terhadap impulsive buying behavior. Konsumen Taiwan yang berbelanja impulsif secara online yang memiliki sifat agreeableness dapat mempengaruhi perilaku belanja. Individu dengan sifat agreeableness cenderung menyenangkan dan dapat menjadi jembatan dalam situasi sosial dan mudah percaya. Hal ini menjadikan konsumen kurang berhati-hati, memiliki tingkat kepercayaan yang tinggi pada para penjual, yang tidak akan menghalangi dorongan untuk membeli. Konsumen 
dengan kurangnya perencanaan dan membuat evaluasi, memiliki hubungan interpersonal yang kuranag baik, dan kurangnya otonomi membuat mereka mudah terpengaruh mencirikan pembeli impulsif.

Penelitian ini bertujuan meneliti kepribadian big five terhadap impulsive buying behavior. Peneliti tertarik memfokuskan pada konsumen perempuan, khususnya kepada mahasiswi yang mana konsumen perempuan dalam pengambilan keputusan pembelian cenderung dipengaruhi oleh sisi emosional. Hal ini didukung dengan mahasiswa yang sedang berada di dalam masa transisi antara remaja menuju ke dewasa yang membuat pengambilan keputusan yang dilakukan oleh mahasiwi masih banyak dipengaruhi oleh teman sebaya dan sisi emosi yang sering menghambat kemampuan pengambilan keputusan dan ceroboh. Mahasiwa yang sedang kuliah di Fakultas Ekonomi dan Bisnis Universitas Airlangga Surabaya tentunya memiliki pengetahuan yang lebih baik dalam mengatur masalah finansial. Adanya pengetahuan dan kemampuan yang seharusnya dimiliki dapat diaplikasikan pada diri pribadi sehingga mampu mengontrol diri dari impulsive buying behavior.

\section{METODE}

Penelitian ini menggunakan metode penelitian kuantitatif sebab-akibat, populasi dalam penelitian ini adalah mahasiswi Fakultas Ekonomi dan Bisnis Universitas Airlangga Surabaya dan didapatkan sampel sebesar 115 responden dengan menggunakan teknik samping accidental sampling. Pengumpulan data menggunakan skala adaptasi, yaitu skala MINI-IPIP dari Donnellan, dkk. (2006) dan skala impulsive buying behavior yang dikembangkan oleh Rook dan Fisher (1995). Data yang terkumpul dianalisis menggunakan regresi linier berganda dengan bantuan SPSS 21. Penelitian ini menggunakan kuesioner sebagai instrument penelitian, yaitu kepribadian big five dan impulsive buying behavior. Kedua skala tersebut penyusunannya menggunakan skala likert. Kepribadian big five diukur menggunakan skala MINI-IPIP yang diadaptasi dan telah dialihbahasakan yang terdiri dari 20 aitem. Impulsive buying behavior diukur menggunakan skala impulsive buying behavior yang diadaptasi dan telah dialihbahasakan dengan total 9 aitem. Koefisien reliabilitas skala MINI-IPIP dan skala impulsive buying behavior setelah diujicobakan sebesar 0,648-0,791 dan 0,873 secara berturut-turut. 
Putri Puji Astutik dkk | Kepribadian Big Five

\section{PAPARAN HASIL}

Hasil penelitian terhadap kepribadian big five dan impulsive buying behavior dapat dilihat pada tabel berikut.

Tabel 1. Hasil Deskriptif

\begin{tabular}{lcccc}
\hline & Mean & $\begin{array}{c}\text { Standar } \\
\text { Deviasi }\end{array}$ & Minimum & Maksimum \\
\hline Extraversion & 10,48 & 4,107 & 1 & 20 \\
\hline Agreeableness & 12,65 & 3,280 & 2 & 19 \\
\hline Conscientiousness & 12,82 & 2,952 & 3 & 19 \\
\hline Neuroticism & 10,62 & 3,142 & 4 & 18 \\
\hline Openness to Experience & 11,97 & 2,750 & 5 & 18 \\
\hline Impulsive Buying Behavior & 20,83 & 9,466 & 0 & 45 \\
\hline
\end{tabular}

Berdasarkan tabel 1 diketahui bahwa kepribadian conscientiousness memiliki nilai rata-rata sebesar 12,82 dengan deviasi standar sebesar 2,952, tertinggi dibandingkan dengan kepribadian extraversion, agreeableness, neuroticism, dan openness to experience yang memiliki nilai rata-rata secara berurutan sebesar 10.48, 12.65, 10.62, dan 11.97 dengan deviasi standar sebesar 4.107, 3.280, 3.142, dan 2.750 berturut-urut. Sedangkan impulsive buying behavior memiliki nilai rata-rata sebesar 20,83 dengan deviasi standar sebesar 9,466.

Tabel 2. Klasifikasi Skor T

\begin{tabular}{lccc}
\hline & Skor T & Skor T & Persentase \\
\hline Extraversion & $\mathrm{T}>50$ & 58 & $50,43 \%$ \\
& $\mathrm{~T} \leq 50$ & 57 & $49,57 \%$ \\
\hline Agreeableness & $\mathrm{T}>50$ & 60 & $52,17 \%$ \\
& $\mathrm{~T} \leq 50$ & 55 & $47,83 \%$ \\
\hline Conscientiousness & $\mathrm{T}>50$ & 62 & $53,91 \%$ \\
& $\mathrm{~T} \leq 50$ & 53 & $46,09 \%$ \\
\hline Opeuroticism & $\mathrm{T}>50$ & 61 & $53,04 \%$ \\
& $\mathrm{~T} \leq 50$ & 54 & $46,96 \%$ \\
\hline Impulsive Buying Behavior & $\mathrm{T}>50$ & 69 & $60,00 \%$ \\
& $\mathrm{~T} \leq 50$ & 46 & $40,00 \%$ \\
\hline
\end{tabular}

Tabel 2 yang merupakan klasifikasi skor $\mathrm{T}$ diketahui bahwa kepribadian extraversion, agreeableness, conscientiousness, neuroticism, dan openness to experience memiliki skor T diatas 50 Persentase extraversion sebesar 50,43\%, agreeableness sebesar $52,17 \%$, conscientiousness sebesar $53,91 \%$, neuroticism sebesar $53,04 \%$, dan openness to experience sebesar $60,00 \%$. Sedangkan impulsive buying behavior memiliki skor T dibawah 50 lebih tinggi, yaitu 60 dengan persentase sebesar $52,17 \%$. 
Putri Puji Astutik dkk | Kepribadian Big Five

Tabel 3. Analisis Regresi Linier Berganda Pengaruh Kepribadian Big Five Terhadap Impulsive Buying Behavior

\begin{tabular}{lcccc}
\hline Variabel & R & R Square & $\begin{array}{c}\text { Adjusted R } \\
\text { Square }\end{array}$ & SEE \\
\hline $\begin{array}{l}\text { Kepribadian Big Five terhadap } \\
\text { Impulsive Buying Behavior }\end{array}$ & 0,372 & 0,138 & 0,099 & 8,987 \\
\hline
\end{tabular}

Berdasarkan tabel 3 diketahui bahwa kepribadian big five berpengaruh terhadap impulsive buying behavior. Kepribadian big five dapat menjelaskan impulsive buying behavior sebesar $13,8 \%$, sedangkan sisanya sebesar $86,2 \%$ dapat dijelaskan oleh variabel lainnya di luar variabel yang dipergunakan dalam penelitian ini.

Tabel 4. Nilai Beta Kepribadian Big Five terhadap Impulsive Buying Behavior

\begin{tabular}{lcc}
\hline Dimensi & B & Signifikansi \\
\hline Extraversion & 0,369 & 0,113 \\
\hline Agreeableness & 0,591 & 0,069 \\
\hline Conscientiousness & $-0,916$ & 0,003 \\
\hline Neuroticism & 0,038 & 0,890 \\
\hline Openness to experience & $-0,302$ & 0,352 \\
\hline
\end{tabular}

Tabel 4 menunjukkan bahwa kepribadian conscientiousness merupakan kepribadian yang berpengaruh secara signifikan terhadap impulsive buying behavior. Sedangkan kepribadian extraversion, agreeableness, neuroticism, dan openness to experience tidak memiliki pengaruh signifikan terhadap impulsive buying behavior.

Tabel 5. Kepribadian Big Five Terhadap Impulsive Buying Behavior

\begin{tabular}{ll}
\hline Dimensi & Pengaruhnya terhadap impulsive buying behavior \\
\hline Extraversion & $\begin{array}{l}\text { Penuh kasih sayang, mudah bergaul, banyak bicara, menyukai kesenangan, } \\
\text { aktif, dan bersemangatmemiliki peluang yang lebih tinggi dijadikan target } \\
\text { penjualan karena mempunyai kecenderungan berkomunikasi secara bebas. } \\
\text { Extraversion memiliki pengaruh positif tidak signifikan terhadap impulsive } \\
\text { buying behavior }\end{array}$ \\
\hline Agreeableness & $\begin{array}{l}\text { Berhati lembut, mudah percaya, dermawan, ramah, toleran, dan } \\
\text { bersahabat. Agreeableness berpengaruh positif tidak signifikan terhadap } \\
\text { impulsive buying behavior }\end{array}$ \\
\hline Conscientiousness & $\begin{array}{l}\text { Teliti, pekerja keras, teratur, tepat waktu, ambisius, dan gigih. } \\
\text { Conscientiousness berpengaruh negatif terhadap impulsive buying behavior } \\
\text { Neuroticism } \\
\text { secara signifikan }\end{array}$ \\
\hline Opencemas, temperamental, sentimental, emosional, dan rentan terhadap \\
Stress. Neuroticism berpengaruh positif tidak signifikan terhadap impulsive \\
buying behavior
\end{tabular}




\section{PEMBAHASAN}

Berdasarkan hasil analisis yang telah dilakukan sebelumnya didapatkan hasil bahwa Mahasiswi Fakultas Ekonomi dan Bisnis Universitas Airlangga Surabaya memiliki impulsive buying behavior yang termasuk dalam kategori rendah. Hasil temuan ini berbeda dengan Mahindra (2018) yang mengatakan bahwa konsumen perempuan menyatakan setuju dalam pembelian impulsif. Hal ini dikarenakan perempuan lebih terpengaruh oleh alasan emosionalnya. Individu dengan kemampuan kontrol diri yang baik cenderung menjadi konsumen cerdas yang mengelola belanjanya dengan bijak, sedangkan individu dengan kontrol diri yang rendah akan menjadi pembeli impulsif.

Berdasarkan data yang dipaparkan di atas menunjukkan bahwa Mahasiswi Fakultas Ekonomi dan Bisnis Universitas Airlangga Surabaya memiliki kecenderungan kepribadian big five dominan. Individu dengan kepribadian extraversion yang tinggi cenderung aktif, banyak berbicara, menyenangkan, dan mempunyai kemampuan untuk menjalin hubungan interpersonal dengan baik. Menurut Soto (2018) Individu dengan extraversion tinggi cenderung mempunyai lebih banyak teman dan dilihat oleh rekan-rekan mereka serta memiliki status sosial yang lebih tinggi. Lalu, individu dengan agreeableness tinggi adalah individu yang bersifat adapter, mampu beradaptasi dengan mudah dengan lingkungannya, rendah hati, dan suka menolong, serta sabar. Skala keramahan membedakan antara orangorang yang berhati lembut dengan mereka yang kejam. Orang-orang yang memiliki kepribadian yang mengarah pada keramahan cenderung mudah percaya, murah hati, pengalah, mudah menerima, dan memiliki perilaku yang baik (Feist dkk., 2017).

Sedangkan conscientiousness yang dominan cenderung lebih disiplin, berhati-hati, dan memiliki daya tahan lebih baik. Individu dengan kepribadian conscientiousness cenderung proaktif, mengejar terus sesuai dengan tujuan motivasi nilai pencapaian prestasi, berkomitmen untuk memenuhi tugas dan kewajibannya, dan berhati-hati sehingga membuat mereka dapat menjalani aktivitasnya lebih teratur dan disiplin karena mereka lebih suka hidupnya lebih teroganisir (Feist dkk., 2017; Soto, 2018). Di sisi lain, individu dengan neuroticism dominan cenderung penuh kecemasan, tempramental, sadar akan diri sendiri, dan rentan terhadap gangguan yang berhubungan dengan stres. Menurut Soto (2018), neuroticism berhubungan negatif dengan kesejahteraan subjektif dan kesehatan psikologis. Individu yang sangat neurotik cenderung mengalami tingkat kepuasan hidup keseluruhan yang lebih rendah, serta kepuasan yang lebih rendah di sejumlah domain kehidupan tertentu, misalnya kepuasan kerja dan hubungan. Kemudian, kepribadian openness to experince cenderung intelektual, imajinatif, sensitif, dan berpikiran terbuka. Individu dengan openness to experience dominan mempunyai otonomi yang tinggi terhadap 
pemikiran, pembelajaran, dan tindakan serta terbuka terhadap gagasan dan pengalaman baru (Feist dkk., 2017; Soto, 2018).

Penelitian ini menunjukkan hasil bahwa kepribadian seseorang memiliki pengaruh terhadap Impulsive buying behavior. Pembelian impulsif sering terjadi pada individu khususnya pada perempuan karena dipengaruhi oleh sisi emosionalnya daripada segi rasionalitasnya dan tidak bisa mengontrol dirinya sehingga pembelian barang pun dapat terjadi tanpa adanya perencanaan sebelumnya. Hasil penelitian ini sejalan dengan Gohary dan Hanzaee (2014), Badgaiyan dkk. (2016), dan Looi dkk. (2016) yang mengatakan bahwa kepribadian big five berpengaruh terhadap impulsive buying behavior seseorang. Individu yang aktif, mudah bergaul, ramah, dan memiliki toleransi yang tinggi akan lebih mudah percaya terhadap persuasi dari orang lain lalu akan menuruti keinginan dari orang tersebut. Looi dkk. (2016) berpendapat bahwa individu yang suka berbicara dan mudah bergaul memiliki peluang yang lebih tinggi dijadikan target penjualan karena mempunyai kecenderungan berkomunikasi secara bebas. Hal ini akan menjadikan seseorang bertindak impulsif dan ingin segera mendapatkan produknya.

Selain itu, seseorang yang emosional cenderung mengalihkan emosi negatifnya melalui belanja. Berbelanja akan mengurangi stres yang sedang dialami oleh seseorang dan kebahagiaan akan meningkat. Individu yang memiliki sifat teliti dan kehati-hatian cenderung akan mencari dan mengumpulkan informasi secara terbuka untuk memastikan bahwa apa yang akan dilakukannya benar dan sukses (Badgaiyan dkk., 2016). Sedangkan individu dengan otonomi yang lebih rendah akan membuat mereka mudah untuk dipengaruhi oleh orang lain dan memiliki kemungkinan impulsive buying behavior lebih tinggi. Dengan kata lain dapat dijelaskan bahwa individu yang cenderung kurang teliti dan kurangnya sifat kehati-hatian akan menjadi impulsive buying behavior karena minimnya informasi yang diterima. Hal lain, dimana individu yang kurangnya rasa keingintahuan membuatnya kurang berminat untuk mencari informasi menjadikan minim informasi sehingga mudah untuk percaya pada orang lain dan akan membeli produk atau barang yang ditawarkan.

\section{KESIMPULAN}

Berdasarkan penelitian yang telah dilakukan dapat disimpulkan bahwa 1) Mahasiswi Fakultas Ekonomi dan Bisnis Universitas Airlangga Surabaya memiliki impulsive buying behavior rendah sehingga dapat dikatakan bahwamereka memiliki kontrol diri yang cukup baik untuk menahan diri akan dorongan adanya keinginan untuk melakukan belanja diluar dari daftar belanja yang telah disusun; 2) Kepribadian big five pada Mahasiswi 
Fakultas Ekonomi dan Bisnis Universitas Airlangga Surabaya memiliki kecenderungan yang dominan pada setiap dimensi yang meliputi extraversion, agreeableness, conscientiousness, neuroticism, dan openness to experience; 3) Kepribadian big fiveberpengaruh secara signifikan terhadap impulsive buying behavior pada mahasiswi Fakultas Ekonomi dan Bisnis Universitas Airlangga Surabaya. Kepribadian conscientiousnessmerupakan kepribadian yang berpengaruh secara signifikan terhadap impulsive buying behavior dibandingan denganextraversion, agreeableness, neuroticism, dan openness to experience.

\section{DAFTAR PUSTAKA}

Badgaiyan, A. J., Verma, A., \& Dixit, S. (2016). Impulsive buying tendency: Measuring important relationships with a new perspective and an indigenous scale. IIMB Management Review, 28(4), 186-199. https://doi.org/10.1016/j.iimb.2016.08.009

Chen, T., \& Lee, M.-C. (2015). Personality Antecedents of Online Buying Impulsiveness. Journal of Economics, Business and Management, 3(4), 425-429. https://doi.org/10.7763/JOEBM.2015.V3.222

Donnellan, M. B., Oswald, F. L., Baird, B. M., \& Lucas, R. E. (2006). The Mini-IPIP Scales: Tinyyet-effective measures of the Big Five Factors of Personality. Psychological Assessment, 18(2), 192-203. https://doi.org/10.1037/1040-3590.18.2.192

Feist, J., Feist, G. J., \& Tomi-Ann Roberts. (2017). Teori Kepribadian 2 (E8). Salemba Humanika.

Gohary, A., \& Hanzaee, K. H. (2014). Personality Traits as Predictors of Shopping Motivations and Behaviors: A Canonical Correlation Analysis. Arab Economic and Business Journal, 9(2), 166-174. https://doi.org/10.1016/j.aebj.2014.10.001

Khan, N., Hui Hui, L., Booi Chen, T., \& Yong Hoe, H. (2015). Impulse Buying Behaviour of Generation $Y$ in Fashion Retail. International Journal of Business and Management, 11(1), 144. https://doi.org/10.5539/ijbm.v11n1p144

Lejoyeux, M., \& Weinstein, A. (2010). Compulsive Buying. The American Journal of Drug and Alcohol Abuse, 36(5), 248-253. https://doi.org/10.3109/00952990.2010.493590

Looi, K. Y., Lee, S. N., Low, Y. Y., Tey, E. E., \& Yeo, K. W. (2016). The Relationship Between Big Five Model and Impulsive Buying Behaviour of Middle Income Families In Peninsular Malaysia: A Study on Post GST Implementation.

Mahindra, R. (2018). Analisis Perbedaan Gender terhadap Pembelian Impulsif (Studi Pembelian Impulsif di Distro ROWN Surakarta] [S1, Universitas Muhammadiyah Surakarta].

http://eprints.ums.ac.id/65655/10/pernyataan\%20Publikasi\%20rangga.pdf

Rook, D. W., \& Fisher, R. J. (1995). Normative Influences on Impulsive Buying Behavior. Journal of Consumer Research, 22(3), 305. https://doi.org/10.1086/209452 
Santrock, J. W. (2012). Life-Span Development: Perkembangan Masa-Hidup (13 ed.). Erlangga.

Sari, R. K. (2016). Kecenderungan Perilaku Compulsive buying (Pembelian Kompulsif) pada Masa Remaja Akhir di Samarinda. Jurnal Ilmiah Psikologi, 4(4), 361-372.

Soto, C. J. (2018). Big Five Personality Traits. Dalam M. H. Bornstein, The SAGE Encyclopedia of Lifespan Human Development. SAGE Publications, Inc. https://doi.org/10.4135/9781506307633.n93

Utami, C. W. (2010). Manajemen Ritel Strategi dan Implementasi Operasional Bisnis Ritel Modern Di Indonesia. Salemba Empat.

Workman, L. (2010). The Essential Structure of Compulsive Buying: A Phenomenological Inquiry. 